\title{
USE OF MINI POLYTUNNELS FOR THE MAINTENANCE OF A CLONE GARDEN OF ACACIA MEARNSII DE WILDEMAN IN DIFFERENT SEASONS OF THE YEAR
}

\author{
Mara Luana Engel $^{1 *}$, Paulo César Flôres Junior ${ }^{1}$, Angela Cristina Ikeda ${ }^{1}$, Giovana Bomfim de Alcantara ${ }^{1}$, \\ Antonio Rioyei Higa ${ }^{1}$ \\ 1* Federal University of Paraná, Department of Forestry Sciences, Curitiba, Paraná, Brazil - maraluana_pzo@ hotmail.com*; \\ paulocesarfloresjunior@gmail.com; aikeda@ufpr.br; giobomfim@hotmail.com; higa@ufpr.br \\ Received for publication: 27/01/2018 - Accepted for publication: 20/04/2018
}

\begin{abstract}
The aim of this study was to verify the influence of mini polytunnels on the quality of shoots produced in a black wattle clone garden. The treatments used were: T1 - clone garden with mini polytunnels inside the greenhouse; T2 - clone garden with no mini polytunnels inside the greenhouse; T3 - clone garden with mini polytunnels outside the greenhouse; and T4 - clone garden with no mini polytunnels outside the greenhouse. These four treatments formed a 4 x 3 factorial along with three seasons of the year: winter/2015, summer/2015-2016, and autumn/2016. A randomized block design was used with six blocks and ten cuttings per plot. Survival rate, number of shoots per cutting, and mean shoot length were evaluated. Shoots were collected from the cuttings and a rooting experiment with the same design was installed. Rooting rate, rate of shoots with calluses, number of roots per shoot, and mean shoot length per cutting were evaluated. There was interaction between the environment in the clone garden and the season of the year. In the winter, the treatment with mini polytunnels outside the greenhouse (T3) showed the best results, mainly in what concerns to the rooting of shoots. Shoots survived in the four clone garden environments, and the lowest survival rates were observed in the autumn/2016 season. The best responses were observed in the summer season.

Keywords: Environmental conditions, cutting, rooting.
\end{abstract}

\section{Resumo}

Uso de estufins na manutenção de minijardim clonal de Acacia mearnsii De Wildman em diferentes estações do ano. O objetivo deste trabalho foi verificar a influência do uso de estufins na qualidade de miniestacas produzidas em minijardins clonais de acácia negra. Os tratamentos utilizados foram: T1 - minijardim clonal com estufim dentro da casa de vegetação; T2 - minijardim clonal sem estufim dentro da casa de vegetação; T3 - minijardim clonal com estufim fora da casa de vegetação e T4 - minijardim clonal sem estufim fora da casa de vegetação. Esses quatro tratamentos formaram um fatorial com três estações do ano (4 x 3): inverno/2015, verão/2015-2016 e outono/2016. O delineamento foi instalado em blocos casualizados, com seis blocos e dez minicepas por parcela. Foram avaliados: sobrevivência, número de brotações por minicepa e comprimento médio das brotações. Foram coletadas miniestacas das minicepas e instalado o experimento de enraizamento com o mesmo delineamento. Avaliou-se: porcentagem de enraizamento, porcentagem de miniestacas com calos, número de raízes por miniestaca e comprimento médio de raízes por miniestaca. Observou-se interação entre a condição do minijardim clonal e a estação do ano, sendo que, no inverno, o tratamento com uso de estufim fora da casa de vegetação (T3) apresentou os melhores resultados, principalmente para enraizamento de miniestacas. As minicepas sobreviveram nos quatro ambientes de minijardim clonal, e as menores porcentagens de sobrevivência foram observadas na estação do outono/2016. $\mathrm{Na}$ estação do verão, verificaram-se as melhores respostas aos tratamentos.

Palavras-chave: Condições ambientais, minicepas, enraizamento.

\section{INTRODUCTION}

Cloning cuttings of selected genotypes have been a common process among Brazilian eucalyptus tree breeders due to their uniformity, yield and wood quality. As a result, this practice can also be advantageous for foresters who produce cuttings of other forest species. However, the adoption of this method in the current scenario still depends on the development and improvement of vegetative propagation methodologies for other species.

The cutting process has been widely adopted by Brazilian forestry companies for the cloning of eucalyptus trees, which has led to a decrease in the dimensions of the clone garden (BRONDANI et al., 2012). In this method, vegetative propagules called cuttings are obtained by collecting shoots from a stem rooted by cutting, or from seedlings. Shoots usually range from 4 to $8 \mathrm{~cm}$ in length, and contain one, two or three pairs of leaves

FLORESTA, Curitiba, PR, v. 48, n. 4, p. 601-608, out/dez. 2018

Engel. M. L. et.al.

ISSN eletrônico 1982-4688

DOI: $10.5380 /$ rf.v48i4.57602 
(XAVIER et al., 2013). Most of the clone gardens of forest species are established in a semi-hydroponic system, inside greenhouses in plastic tubes, or in channels made from fiber cement with a drip fertigation or subirrigation system (ALFENAS et al., 2009; ANDREJOW; HIGA, 2009).

The main factors involved in the rooting of shoots are: occurrence of diseases; hormonal balance; genetic constitution of the parent plant (potential and genetic variability within the species); endogenous inhibitor level; nutritional and water conditions of the parent plant; oxidation reactions at the base of the cuttings; propagule senescence; season of collection; abiotic factors (temperature, light, humidity); use of plant regulators; and substrate quality (ALFENAS et al., 2009; XAVIER et al., 2013).

Knowing the ideal conditions of luminosity, temperature and relative humidity for the growth and development of plants is of paramount importance for an efficient propagation protocol, either in vitro or directly in the substrate (CUNHA et al., 2009). It must be emphasized that each species has specific requirements for its development. Irrigation, photoperiod and light quality should be suitable in order to maintain a photosynthetic rate that guarantees enough carbohydrate supply for the survival of the shoots and root initiation without compromising their vegetative vigor (HARTMANN et al., 2011).

Studies show that a decrease in the levels of natural light induces better rooting of shoots in the Brazilian climatic conditions (ALFENAS et al., 2009). However, in shoots with leaves, the products of photosynthesis are essential for the rooting process. The intensity and duration of the light should be sufficient for the accumulation of carbohydrates in order to favor rooting. Therefore, the effect of seasonality on the induction of rhizogenic processes in vegetative propagules can be determinant in commercial cloning, especially by influencing their collection time (HARTMANN et al., 2011).

Abiotic factors influence the quality of shoots in a clone garden and, consequently, in the rooting of the cuttings. By identifying the best seasons and management conditions, one can optimize the large-scale production of cuttings of selected genotypes. Therefore, the objective of this study was to verify the influence of the use of mini polytunnels in clone gardens inside and outside a greenhouse in different seasons of the year, as well as its influence on the rooting of Acacia mearnsii De Wildeman shoots.

\section{MATERIAL AND METHODS}

\section{Characterization of the study area and maintenance of the clone garden}

The experiment took place in the city of Triunfo (state of Rio Grande do Sul, Brazil), located at 29 41' 19' South latitude, $51^{\circ} 27^{\prime} 40^{\prime \prime}$ West longitude, and situated at 31 meters above sea level (IBGE, 2010). The experiments were conducted in three seasons: July/2015 (winter), January/2016 (summer), and April/2016 (autumn), in a greenhouse belonging to the company TANAC S.A. The city is located in the South Subtropical Zone, whose climate is defined as Cfa, that is, humid temperate climate with hot summers (ALVARES et al., 2013).

The genetic material used was a commercial clone called B, which presents better performance for the rooting detected by the company. The clone gardens were set up in channels assembled inside and outside the greenhouse, with and without the use of mini polytunnels, which were made from transparent plastic (polypropylene) and included a retractable roof that covered the whole channel. The plants were pruned at intervals of about 15 days, between the intervals of the seasonal evaluations defined for the experiment.

\section{Analyzed variables}

Four treatments were contemplated in the experiment: $\mathrm{T} 1$ - clone garden with mini polytunnels inside the greenhouse (GH); T2 - clone garden with no mini polytunnels inside the greenhouse; T3 - clone garden with mini polytunnels outside the greenhouse; and T4 - clone garden with no mini polytunnels outside the greenhouse.

A 4 x 3 factorial scheme based on the number of seasons (3) and treatments (4) was used in a randomized block design, with six replicates of ten plants per plot, totaling 240 cuttings evaluated in the three seasons of the year (720 shoots).

The plants were evaluated for quality and productivity, taking into account the cutting survival rate, number of shoots produced per cutting, mean shoot length per cutting, and rooting of the shoots resulting from the cuttings.

The conditions of relative humidity and temperature in the clone gardens were measured daily at 09 a.m. and 03 p.m. throughout the whole experiment period. In order to prevent the temperature from exceeding $35^{\circ} \mathrm{C}$, the opening of the retractable roof of the mini polytunnels was controlled during the warmest times of the day. During the warmest summer and spring seasons, the plastic cover was replaced with 50 percent shade cloth to minimize the burning of shoots. 


\section{Rooting tests}

Shoots were collected from the cuttings in the clone garden for greenhouse propagation as well as survival and rooting tests. They were prepared with dimensions of 10 to $12 \mathrm{~cm}$ in length and with one to two pairs of leaves. The leaf area was reduced to half its original size and a bevel cut was made in the base.

The shoots were placed in $55 \mathrm{~cm}^{3}$ tubes containing substrate composed of rice husk $(50 \%)$ and medium vermiculite (50\%). Three $\mathrm{kg} \mathrm{m}^{-3}$ of Osmocote fertilizer were applied. Shoots were treated with 4,000 $\mathrm{mg} \mathrm{L}^{-1}$ of indole butyric acid (IBA) powder, according to the methodology used in the company, and remained in the greenhouse with controlled temperature and relative humidity. The average temperature remained around 25 to $30{ }^{\circ} \mathrm{C}$ and the relative humidity ranged from 90 to $95 \%$. Nebulization was performed for 10 seconds every 15 minutes.

The evaluation of shoots was carried out approximately 45 days after the cutting process. The following traits were evaluated: rate of rooted shoots, number of roots per shoot, and length of the three largest roots formed per shoot.

\section{Statistical analyses}

Data normality was evaluated by the Shapiro-Wilk test and the homogeneity of the variances was evaluated by the Bartlett test with significance at $5 \%$ probability. The $F$-test was applied to the variables whose variances were homogeneous. The non-homogeneous variances were transformed by $\sin (\mathrm{x})+1$. Mean comparison was performed by the Scott-Knott test. The survival analysis was performed by Friedman's non-parametric test with significance at 5\% probability. The analyses were performed with the aid of the software Assistat 7.7 statistical (SILVA; AZEVEDO, 2016).

\section{RESULTS}

There were differences between treatments in what concerns to the number of shoots per individual and only a factorial difference for mean shoot length per individual. The clone garden with no mini polytunnels showed the best result per cutting. The best season of the year was summer, followed by autumn and winter, which presented fewer shoots. Considering the significant interaction between the factors, the best results for number of shoots per individual were observed in the summer and autumn in the clone garden with no mini polytunnels inside the greenhouse. In the autumn, the best result was observed in the clone garden with mini polytunnels outside the greenhouse. In the summer, the best result was observed in the clone garden with no mini polytunnels outside the greenhouse. In general, the best responses to the treatments were observed in the summer season (Table 1).

Table 1. Number of shoots per cutting and mean shoot length per cutting of A. mearnsii De Wildeman individuals in a clone garden under different conditions and seasons.

Tabela 1. Número de brotações por minicepa e comprimento médio de brotações por minicepa de A. mearnsii De Wildeman, provenientes de minijardim clonal sob diferentes condições e em diferentes épocas do ano.

\begin{tabular}{|c|c|c|c|c|c|c|}
\hline \multirow[b]{2}{*}{ Variable } & \multirow[b]{2}{*}{ Season } & \multicolumn{4}{|c|}{ Clone Garden Conditions } & \multirow[b]{2}{*}{ Means } \\
\hline & & $\begin{array}{l}\text { GH + Mini } \\
\text { Polytunnel } \\
\end{array}$ & $\begin{array}{l}\text { GH - Mini } \\
\text { Polytunnel }\end{array}$ & $\begin{array}{l}\text { Mini } \\
\text { Polytunnel }\end{array}$ & $\begin{array}{l}\text { No Mini } \\
\text { Polytunnel }\end{array}$ & \\
\hline \multirow{4}{*}{$\begin{array}{l}\text { Number of shoots per } \\
\text { cutting }\end{array}$} & Winter & $6.28 \mathrm{bA}$ & $8.22 \mathrm{bA}$ & $6.15 \mathrm{bA}$ & $6.62 \mathrm{bA}$ & $6.82 \mathrm{c}$ \\
\hline & Summer & $7.33 \mathrm{aB}$ & $10.92 \mathrm{aA}$ & $8.60 \mathrm{aB}$ & $9.87 \mathrm{aA}$ & $9.18 \mathrm{a}$ \\
\hline & Autumn & $6.33 \mathrm{aB}$ & $10.83 \mathrm{aA}$ & $9.00 \mathrm{aA}$ & $5.67 \mathrm{bB}$ & $7.96 \mathrm{~b}$ \\
\hline & Means & $6.65 \mathrm{~B}$ & $10.00 \mathrm{~A}$ & $7.92 \mathrm{~B}$ & $7.38 \mathrm{~B}$ & 7.98 \\
\hline \multirow{4}{*}{$\begin{array}{l}\text { Mean shoot length per } \\
\text { cutting }(\mathrm{cm})\end{array}$} & Winter & $13.62 \mathrm{bA}$ & $15.91 \mathrm{aA}$ & $15.05 \mathrm{bA}$ & $14.58 \mathrm{bA}$ & $14.79 \mathrm{a}$ \\
\hline & Summer & $16.18 \mathrm{aA}$ & $19.37 \mathrm{aA}$ & $12.86 \mathrm{bB}$ & $17.76 \mathrm{aA}$ & $16.54 \mathrm{a}$ \\
\hline & Autumn & $15.69 \mathrm{aB}$ & $15.86 \mathrm{aB}$ & $23.69 \mathrm{aA}$ & $14.40 \mathrm{aB}$ & $17.41 \mathrm{a}$ \\
\hline & Means & $15.16 \mathrm{~A}$ & $17.04 \mathrm{~A}$ & $17.20 \mathrm{~A}$ & $15.58 \mathrm{~A}$ & 16.25 \\
\hline
\end{tabular}

In which: GH + Mini Polytunnel: clone garden with mini polytunnels inside the greenhouse; GH - Mini Polytunnel: clone garden with no mini polytunnels inside the greenhouse; Mini Polytunnel: clone garden with mini polytunnels outside the greenhouse; No Mini Polytunnel: clone garden with no mini polytunnels outside the greenhouse. ${ }^{1}$ Means followed by the same lower-case letter in the columns and same upper-case letter in the rows are not statistically different from each other according to the Scott-Knott test at $5 \%$ and $1 \%$ probability. 
In relation to shoot length, the best treatment was observed in autumn with mini polytunnels outside the greenhouse (T3). In summer, there were no significant differences between treatments, except for T3, which yielded the lowest result. As for winter, there were no significant differences in shoot length between treatments (Table 1).

By comparing the yield of the cuttings during the different seasons of the year and the treatments under different maintenance conditions, it is possible to notice interaction between factors for all variables, except for the survival rate of shoots. The season of the year was a significant factor for all variables, except for mean shoot length. The clone garden condition had a significant influence on the number of shoots per cutting and rate of rooted shoots. Survival rate of shoots was evaluated for each clone garden condition only in the autumn, since no interaction between these factors was detected. By comparing the means, it is observed that in autumn T4 presented lower survival rates (Table 2). During the other seasons, survival rate was $100 \%$.

Table 2. Survival rate of shoots of A. mearnsii De Wildeman in a clone garden under different conditions in autumn.

Tabela 2. Porcentagem de sobrevivência das minicepas de A. mearnsii De Wildeman, provenientes de minijardim clonal sob diferentes condições, na estação do outono.

\begin{tabular}{lll}
\hline Treatment & Survival (\%) & \\
\hline GH + Mini & 95 & $\mathrm{a}$ \\
$\begin{array}{l}\text { Polytunnel } \\
\text { GH - Mini }\end{array}$ & 95 & $\mathrm{a}$ \\
Polytunnel & & $\mathrm{a}$ \\
Mini Polytunnel & 95 & $\mathrm{~b}$ \\
No Mini & 82.5 & \\
Polytunnel & $28.70^{* *}$ & \\
\hline Friedman $\left(\mathrm{X}^{2}\right)$ & 11 & \\
df & &
\end{tabular}

In which: df: degree of freedom; S (\%): survival rate of shoots. ${ }^{1}$ Means followed by the same lower-case letter in the column are not statistically different from each other at $5 \%$ and $1 \%$ probability according to the Friedman test.

The rate of rooted shoots varied according to the season of the year and clone garden condition. It presented interaction between factors. The best season for rooting was summer, followed by autumn. The best clone garden condition was T4. As product of the interaction between factors, rooting was more promising with both T2 and T4 during summer and autumn. However, during winter, the rooting rate was higher in T3, which follows the same pattern observed for shoot yield (Table 3).

The development of roots per rooted shoot was better during autumn. In this season, the best treatment was T4. The seasons of the year represented no difference for the clone garden inside the greenhouse without the use of mini polytunnels; however, values were numerically lower in winter. The best treatment in terms of developed roots during the coldest seasons (winter and autumn) was T3. The clone gardens without plastic cover yielded the best results in autumn and summer, and the worst results in winter.

In what concerns to the mean root length per shoot, the best results were achieved in summer, in both T1 and T2. Treatment T3 did not present significantly different results in the seasons assessed. In the treatments without the use of mini polytunnels, cuttings formed shoots with the best root length results in summer (Table 3 ).

Table 3. Rate of rooted shoots, number of roots per shoot, and mean root length per shoot of A. mearnsii De Wildeman in a clone garden under different conditions and seasons of the year.

Tabela 3. Porcentagem de miniestacas enraizadas, número de raízes por miniestaca e comprimento médio de raízes por miniestaca de $A$. mearnsii De Wildeman, provenientes de minijardim clonal sob diferentes condições, em diferentes épocas do ano.

\begin{tabular}{cllllll}
\hline & \multicolumn{5}{c}{ Clone garden condition } \\
\hline \multirow{2}{*}{ Variable } & $\begin{array}{l}\text { Season of } \\
\text { the year }\end{array}$ & $\begin{array}{l}\text { GH + Mini } \\
\text { Polytunnel }\end{array}$ & $\begin{array}{l}\text { GH - Mini } \\
\text { Polytunnel }\end{array}$ & $\begin{array}{l}\text { Mini } \\
\text { Polytunnel Polytunnel }\end{array}$ & No Mini & Means \\
& Winter & $10.00 \mathrm{bB}$ & $10.00 \mathrm{bB}$ & $40 \mathrm{aA}$ & $20.00 \mathrm{bB}$ & $20.00 \mathrm{c}$ \\
& Summer & $53.33 \mathrm{aB}$ & $71.67 \mathrm{aA}$ & $53.33 \mathrm{aB}$ & $83.33 \mathrm{aA}$ & $65.42 \mathrm{a}$ \\
\multirow{2}{*}{ Rooted shoots (\%) } & Autumn & $34.44 \mathrm{aB}$ & $55.00 \mathrm{aA}$ & $42.30 \mathrm{aB}$ & $74.17 \mathrm{aA}$ & $51.48 \mathrm{~b}$ \\
& & & & & & \\
\cline { 2 - 7 } & Means & $32.59 \mathrm{C}$ & $45.55 \mathrm{~B}$ & $45.21 \mathrm{~B}$ & $59.16 \mathrm{~A}$ & 45.63 \\
\hline
\end{tabular}




\begin{tabular}{|c|c|c|c|c|c|c|}
\hline \multirow{4}{*}{ Number of roots per shoot } & Winter & $3.63 \mathrm{bA}$ & $5.20 \mathrm{aA}$ & $7.64 \mathrm{aA}$ & $3.46 \mathrm{bA}$ & $4.99 \mathrm{~b}$ \\
\hline & Summer & $3.00 \mathrm{bB}$ & $11.16 \mathrm{aA}$ & $4.32 \mathrm{aB}$ & $13.58 \mathrm{aA}$ & $8.02 \mathrm{~b}$ \\
\hline & Autumn & $13.35 \mathrm{aA}$ & $9.14 \mathrm{aA}$ & $12.48 \mathrm{aA}$ & $16.27 \mathrm{aA}$ & $12.81 \mathrm{a}$ \\
\hline & Means & $6.66 \mathrm{~A}$ & $8.52 \mathrm{~A}$ & $8.14 \mathrm{~A}$ & $11.12 \mathrm{~A}$ & 8.61 \\
\hline \multirow{4}{*}{$\begin{array}{l}\text { Mean root length per shoot } \\
\qquad(\mathrm{cm})\end{array}$} & Winter & $2.42 \mathrm{cB}$ & $1.60 \mathrm{cB}$ & $5.88 \mathrm{aA}$ & $2.80 \mathrm{cB}$ & $3.17 \mathrm{c}$ \\
\hline & Summer & $7.90 \mathrm{aA}$ & $8.00 \mathrm{aA}$ & $6.83 \mathrm{aA}$ & $7.20 \mathrm{aA}$ & $7.48 \mathrm{a}$ \\
\hline & Autumn & $5.13 \mathrm{bA}$ & $5.22 \mathrm{bA}$ & $5.23 \mathrm{aA}$ & $5.06 \mathrm{bA}$ & $5.18 \mathrm{~b}$ \\
\hline & Means & $5.17 \mathrm{~A}$ & $4.93 \mathrm{~A}$ & $5.98 \mathrm{~A}$ & $5.02 \mathrm{~A}$ & 5.28 \\
\hline
\end{tabular}

In which: GH + Mini Polytunnel: clone garden with mini polytunnels inside the greenhouse; GH - Mini Polytunnel: clone garden without mini polytunnels inside the greenhouse; Mini Polytunnel: clone garden with mini polytunnels outside the greenhouse; No Mini Polytunnel: clone garden without mini polytunnels outside the greenhouse. ${ }^{1}$ Means followed by the same lower-case letter in the columns and upper-case letter in the rows are not statistically different from each other at $5 \%$ and $1 \%$ probability according to the Scott-Knott test.

Only during winter calluses formed in the shoots. According to the statistical test employed, there was difference between treatments. The highest rate of shoots with calluses was observed in T4 whereas the lowest rate was observed in $\mathrm{T} 1$ (Table 4).

Table 4. Rate of shoots of A. mearnsii De Wildeman with calluses in a clone garden in autumn.

Tabela 4. Porcentagem de miniestacas com calos de A. mearnsii De Wildeman, provenientes de minijardim clonal na estação do outono.

\begin{tabular}{|c|c|c|}
\hline Treatment & Calluses (\%) & \\
\hline $\begin{array}{l}\text { GH + Mini } \\
\text { Polytunnel }\end{array}$ & 7.5 & $\mathrm{~b}$ \\
\hline $\begin{array}{l}\text { GH - Mini } \\
\text { Polytunnel }\end{array}$ & 12.5 & $a b$ \\
\hline Mini Polytunnel & 15 & $a b$ \\
\hline $\begin{array}{l}\text { No Mini } \\
\text { Polytunnel } \\
\end{array}$ & 25 & $\mathrm{a}$ \\
\hline Friedman $\left(\mathrm{X}^{2}\right)$ & $41.73 * *$ & \\
\hline df & 11 & \\
\hline
\end{tabular}

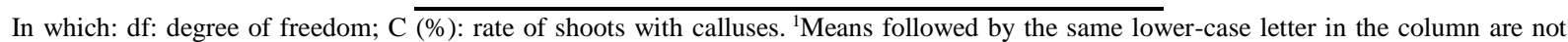
statistically different from each other at $5 \%$ and $1 \%$ probability according to the Friedman test.

The highest temperatures were recorded from December to March, with the maximum reaching $32{ }^{\circ} \mathrm{C}$ in February. The treatments in which the highest temperatures were recorded were the ones inside the greenhouse (T1 and T2). Contrarily, the lowest temperatures were observed from May to July, with the minimum reaching $13.6^{\circ} \mathrm{C}$ in June. Humidity varied greatly, reaching $89.6 \%$ and being remarkably high from April to July (autumn and winter), then dropping in August (65\%). Treatment T1 showed the lowest humidity rates. Such pattern was not expected, since the plastic cover should hold the water vapor inside the micro-environment created in the clone garden.

\section{DISCUSSION}

Survival rate of shoots can be a result of the similarity of both the material employed and the installation conditions in the channels. However, the mortality rate of shoots observed in autumn suggests depletion along the seasons, which caused some shoots to not resist the experiment conditions until the end. One reason for this might be the successive maintenance pruning, in which shoots were removed. Even in small quantity, it might have hindered the shoot's capacity of keeping their vigor and supply of photoassimilates. In addition, shoots were already at an advanced age (approximately 2 years old), thus not showing the desired juvenility. These results indicate that the maintenance of shoots by means of directional pruning has to be readjusted, since this technique, which consists of successive pruning, aims at the invigoration of the parent plant and increase of production of juvenile and vigorous propagules for rooting (XAVIER et al., 2013).

Batista et al. (2015) reported satisfactory results for rooting in a clone garden with mini polytunnels inside a greenhouse in relation to the control clone garden with no mini polytunnels for different species and hybrids of

FLORESTA, Curitiba, PR, v. 48, n. 4, p. 601-608, out/dez. 2018

Engel. M. L. et.al.

ISSN eletrônico 1982-4688 
eucalyptus, in Rio Grande do Sul, Brazil. The authors observed that summer was also the season with the best productivity, when the yield of shoots increased in up to 53\%. According to Alfenas et al. (2009), selective and continuous collection of propagules for rooting depends on temperature, luminous intensity and photoperiod during the different seasons of the year, which are especially well-defined in subtropical regions, such as the south of Brazil. Such factors might have been determining for the results obtained in this study as, in broad terms, it was evident that shoot yield followed the variation of temperature throughout the seasons.

During winter, short days and low temperatures change physiological processes, such as photosynthesis, transport of compounds and substances of the parent plants, what might hinder the rooting of shoots. A study developed by Cunha et al. (2009) reported that meteorological conditions significantly restrict the production of shoots by cuttings. The authors verified that the increase in temperature in the cultivation bed, influenced by the season of the year, positively favored the quality and production of shoots, regardless of the clone garden type.

Assis (2011) states that the use of transparent plastic as cover in clone gardens with mini polytunnels keeps the shoots' environment warm and humid, what increases the productivity and rooting of the shoots. The same was also observed for black wattle individuals during mild temperature seasons (autumn and winter). However, in this study, although the presence of mini polytunnels altered the shoots' environment, this technique was not able to alter the seasonal effects and reverse the decline in shoot production and rooting during the coldest seasons in a subtropical environment.

Altoé et al. (2015) found that the high rates of survival and rooting of araza and guava trees were influenced by the physiological state, temperature and humidity conditions as well as the procedures to which the propagules were subjected. Silva et al. (2012), working with the propagation of Toona ciliata, reported $100 \%$ survival rate of propagules in an experiment that lasted seven months and was conducted in two methods: rows and plastic tubes, with six and four collections, respectively. Souza et al. (2009), also working with Toona ciliata, obtained survival rates above $95 \%$, with three collections in plastic tubes. Wendling (2007) reported $90 \%$ survival rate in a study of yerba mate in a clone garden and 11 collections. These results go in the opposite direction of the results obtained in this study, in which the highest rooting rates were $59 \%$, what can be related to the recalcitrance of the species for the cutting process. The importance of knowing the effects of the factors that affect the development of roots and their implications is related to the success or failure of shoot production via adventitious rooting (CUNHA et al., 2009).

According to Hartmann et al. (2011), calluses are parenchymal cells resulting from new meristematic centers that form close to the vascular bundles next to the phloem. Callus and root formation are independent processes. They occur simultaneously due to both being involved in the cell division process and depend on favorable environmental conditions. In this work, some shoots showed root development without calluses, which was likely caused due to adverse seasonal conditions for rooting. Steupp et al. (2013) reported similar inferences. By assessing different concentrations of IBA along a Melaleuca alternifolia branch, they observed that the low rates of shoots with calluses evidenced the direct rhizogenesis of the culture.

Trueman et al. (2013) verified that environmental temperatures between 28 and $33{ }^{\circ} \mathrm{C}$ resulted in a higher rate of rooting of parent plants from different species. Such results suggest a high sensitivity of cuttings to temperature variations, what significantly influences the pattern of behavior in the production of shoots, as observed in this work. However, other factors must be considered as agents in the rooting process of black wattle shoots, such as the photoperiod and luminous intensity, which might have varied according to the season.

\section{CONCLUSIONS}

- Shoots survive in the four clone garden environments assessed. The lowest survival rates were observed in autumn.

- Summer is the season that presents the best results of number of shoots per cutting, rate of rooted shoots and root length, especially in the clone garden inside the greenhouse.

- The rates of survival and rooting varied according to the clone garden condition and season of the year. In winter, the use of mini polytunnels outside the greenhouse yielded the best results, especially for shoot rate of rooting.

\section{REFERENCES}

ALFENAS, A. C.; ZAUZA, E. A. V.; MAFIA, R. G.; ASSIS, T. F. de. Clonagem e Doenças do Eucalipto. 2. ed. Viçosa, MG: Ed. UFV, 2009. 500 p.

ALTOÉ, J. A.; MARINHO, C. S.; TERRA, M. I. C.; BARROSO, D.G. Propagação de araçazeiro e goiabeira via miniestaquia de material juvenil. Bragantia, Campinas, v. 70, n. 2, p. 312-318, 2011. 
ALVARES, C. A.; STAPE, J.L.; SENTELHAS, P. C.; GONÇALVES, J. L.; SPAROVEK, G. Koppen's climate classification map for Brazil. Metereologische Zeitschrift, v. 22, n. 6, p. 711-728, 2013.

ANDREJOW, G. M. P.; HIGA, A. R. Potencial de enraizamento de miniestacas de Pinus taeda L. provenientes de brotação apical de mudas jovens. Floresta, Curitiba, v. 39, n. 4, p. 897 - 903, 2009.

ASSIS, T. F. Hybrids and mini-cutting: a powerful combination that has revolutionized the Eucalyptus clonal forestry. BMC Proceedings, v. 5, supl. 7, 2011.

BATISTA, A. F.; SANTOS, G. A.; SILVA, L. D.; QUEVEDO, F. F.; ASSIS, T. F. The use of mini-tunnels and the effect of the seasonality in the clonal propagation of Eucalyptus in a subtropical environmental. Australian Forestry, Melbourn, v. 78, n. 2, p. 65-72, 2015.

BRONDANI, G. E.; WIT ONDAS, H. W.; BACCARIN, F. J. B.; GONÇALVES, A. N.; ALMEIDA, M. Micropropagation of Eucalyptus benthamii to form a clonal microgarden. Vitro Cellular \& Developmental Biology - Plant, v. 48, n. 5, p. 478-487, 2012.

CUNHA, A. C. M. C. M.; PAIVA, H. N.; LEITE, H. G.; BARROS, N. F.; LEITE, F. P. Relações entre variáveis climáticas com produção e enraizamento de miniestacas de eucalipto. Revista Árvore, Viçosa, v. 33, n. 2, p.195203, 2009.

HARTMANN; H. T.; KESTER, D. E.; DAVIES JUNIOR, F. T. Plant Propagation: principles and practices. 8 ed. New York: Englewood Clipps: Prentice-Hall, 2011. 647 p.

INSTITUTO BRASILEIRO DE GEOGRAFIA E ESTATÍSTICA (IBGE). Resolução da Presidência do IBGE de $\mathbf{n}^{\circ} 5$ (R.PR-5/02). Consultado em 5 dez. 2010.

SILVA, F. A. S.; AZEVEDO, C. A. V. The Assistat Software Version 7.7 and its use in the analysis of experimental data. African Journal of Agricultural Research, v. 11, n. 39, p. 3733-3740, 2016.

SILVA, M. P. S.; BARROSO, D. G.; SOUZA, J. S.; FERREIRA, D. A.; CARNEIRO, J. G. A. Enraizamento de miniestacas e produtividade de minicepas de cedro australiano em canaletões e tubetes. Ciência Florestal, Santa Maria, v. 22, n. 4, p. 703-713, 2012.

SOUZA, J. C. A. V; BARROSO, D. G.; CARNEIRO, J. G. A.; TEXEIRA, S. L.; BALBINOT, E. Propagação vegetativa de cedro-australiano (Toona ciliata M. Roemer) por miniestaquia. Revista Árvore, Viçosa, v. 33, n. 2, p. 205-213, 2009.

STUEPP, C.A.; PEREIRA, G. P.; MILANI ZEM, L.; PEÑA, M. L.; CENTENARO BUENO, P. M.; SPADER, V.; ZUFFELLATO-RIBAS, K. C.; MACHADO ROSA, G. Enraizamento de melaleuca: influência da altura de coleta das estacas e aplicação de IBA. Colloquium Agrariae, v. 9, n. 1, p. 01-09, 2013.

TRUEMAN, S. J.; MCMAHON, T. V.; BRISTOW, M. Production of cuttings in response to stock plant temperature in the subtropical eucalypts, Corymbia citriodora and Eucalyptus dunnii. New Forests, Queensland, v. 44, n. 2, p. 265-279, 2013.

XAVIER, A.; WENDLING, I.; SILVA, R. L. da. Silvicultura clonal: princípios e técnicas. 2. Ed. Viçosa, MG: Ed. UFV, 2013. 279p.

WENDLING, I.; DUTRA, L. F.; GROSSI, F. Produção e sobrevivência de miniestacas e minicepas cultivadas em sistema semi-hidropônico. Pesquisa Agropecuária Brasileira, Brasília, v. 42, n. 2, p. 289-292, 2007.

FLORESTA, Curitiba, PR, v. 48, n. 4, p. 601-608, out/dez. 2018

Engel. M. L. et.al.

ISSN eletrônico 1982-4688 
FLORESTA, Curitiba, PR, v. 48, n. 4, p. 601-608, out/dez.2018 Engel. M. L. et.al. .ISSN eletrônico 1982-4688 DOI: $10.5380 /$ rf.v48i4.57602 